\title{
Research of Production Practice Promote Development of Higher Education
}

\author{
Chen Yaoxi \\ Xijing University, \\ Shaanxi Xi'an ,China \\ e-mail: 445700839@qq.com
}

\author{
Shang Miao \\ Mechanical and electrical technology department \\ Xijing University, \\ Shaanxi Xi'an ,China \\ e-mail: 445700839@qq.com
}

\begin{abstract}
With In the era of knowledge economy, on the basis of knowledge elements of social production practice has become an important source of knowledge innovation. The production practice plays an important role for the development of modern higher education . Higher education is engaged in the development of knowledge elements, and the relationship between higher education and production practice is more and more closely. In this article, the development of the higher education is discussed in the social production practice; the development of production practice of promoting the knowledge system are illustrated; the diversification of higher education has been analyzed; The production practice of the diversification of higher education is analyzed; the production practice promoted the change of the scale of the higher education quality that is described; the production practice promoted the change of higher education personnel training which is explained; the production practice promoted the change of the contents and forms of the higher education and the improvement of the education function is studied. Social production practice to promote the development of higher education.
\end{abstract}

Keywords- production practice; higher education; knowledge system; talent training; education function

\section{HIGHER EDUCATION DEVELOPMENT IN THE SOCIAL PRODUCTION PRACTICE}

Education of institutions of higher learning, scientific research, production combination is an effective managerial mode. After entering the 21st century, the prospect of the knowledge economy is becoming more and more visible. In the knowledge economy society, the university is the main body of knowledge production and dissemination. Continuously shortening of the knowledge production, distribution and use process. Integration process to carry out education of institutions of higher learning, scientific research, production combining schoolrunning mode provides technical basis. In essence, under the condition of knowledge economy, education, scientific research and production is the combination of institutions of higher learning with knowledge as a link. Rational allocation of resources in the field of education, scientific research, production, unified production, dissemination and application of knowledge, promote the economic construction, science and technology and the coordinated development of higher education process. The mode of running both logically and from the practical point of view, are consistent with the social mode of production requirements of the knowledge economy.
In the knowledge economy society, knowledge is the foundation of the social production practice elements. Factors to provide social production practice and development of knowledge elements. Institutions of higher education has become an important infrastructure of the knowledge economy society. At the same time, the production practice of social development and become an important source of knowledge innovation. Social production practice plays an important role in the development of higher education [1]. Closely connected with the production practice of pre-employment professional education, on-the-job continue education got full development, the specialized level also have a qualitative leap. Higher education and the production practice of mutual promotion and common development.

Higher education is combined with scientific research, production. This combination is of higher learning to carry out "education combined with production and practice guidelines" the specific way. This is the modern higher education "training talents, developing science and technology and services for social and economic development" three basic functions. History shows that, from a single teaching of colleges and universities, and development to the combination of teaching and research, to the combination of teaching, scientific research, production and practice, its function is expanding and the position is ascension. This corresponds to the level of productivity development.

\section{PRODUCTION PRACTICE TO PROMOTE THE}

\section{DEVELOPMENT OF THE KNOWLEDGE SYSTEM OF HIGHER} EDUCATION

On the basis of knowledge elements of social production practice promoted the higher education discipline professional knowledge update, knowledge innovation. Higher education system of subject knowledge in developing and perfecting constantly. When highly differentiated elaboration to deepen professional, different subject fields appear intersection, pay more attention to comprehensive application, emphasis on collaborative innovation [2].

Knowledge system of disciplines and objectively reflect the reality of social production practices, but also provide scientific guidance for the production practice. With the production practice of disciplines complement each other, promote each other. The application value of the knowledge economy to strengthen the knowledge, to strengthen the development of academic disciplines closely connected with the production practice of 
innovation [3]. On the basis of knowledge elements of social production practice has become an important source of knowledge innovation. It promotes the contact closely with the production practice of professional knowledge update and growing fast. It promoted the cross of discipline integration, integrated applications, collaborative innovation. It promotes the new subject, the new professional, the development of new methods.

In addition, to better meet the needs of the production practice of professional talents, especially senior professional talented person's raise more from years of production practice. Product knowledge and professional knowledge, disciplines expertise pay attention to the logic of academic disciplines. A subject under certain conditions in the field of abstract objective law and the basic principle of universal was emphasized that for the pursuit of truth. Focuses on the production practice and product knowledge logic, stressed under the specific situation in specific product as the carrier, highly integrated application of integrated professional knowledge and skills of many subjects [4]. But product knowledge is necessarily on the basis of professional knowledge, the strengthened based on the practical application of subject knowledge ability and the ability to migrate. At the same time in the concrete practice helps to deepen the understanding of abstract knowledge and contribute to innovation and development of academic disciplines related theory of academic disciplines.

\section{THE PRODUCTION PRACTICE TO PROMOTE THE DIVERSIFICATION OF HIGHER EDUCATION}

Knowledge economy makes the study of professional education, professional development. Constantly improve its specialization level, specialized division of labor is becoming more and more developed. Knowledge production are derived from the gradual differentiation service purpose, type, different new type of higher education institutions. Gradually establish a perfect has rich disciplines, professional direction. Geared to the needs of different professions and jobs, with different types of different levels of professional education, professional research system. Both in public services, market service and self-service got full development. Based on the logic of academic disciplines and professional education on the basis of production practice logic system is increasingly perfect, professional research. The interaction and collaboration between different education institutions is becoming more and more closely [5]. More perfect lifelong education system, national innovation system. At the same time, higher education not only has realized the standardization, standardization, scientific, professional, systematic, diversified and popular. And will gradually achieve the higher education popularization, internationalization, network and intelligent diversification, personalization, customization, and even the mercerization, industrialization of education and training.

Modern higher education field is presented an unprecedented, various types and forms of the ecological system. According to the main body of running a school and educational purpose has divided into for-profit and nonprofit institutions of higher education. According to the functions tend to divide teaching type and cu. According to the people training goal of higher vocational education to cultivate vocational education people are divided into ice and cultivating talents of academic and engineering of ordinary higher education [6]. By the training object development stage division of higher education and postcareer higher education before, and so on. In addition, there are created by the parent companies and services maternal enterprises of the university. Service industry university; Relying on science and technology research and development strength leading emerging industry and take the initiative to meet the market demand of entrepreneurial university. Based on a remote network education platform is given priority to with employed adults but at the same time, extensive services in different social group Open University, etc.

External demand of social development to promote the modern higher education in the field of "ecological diversity", also built the "ecological environment" in the development of modern higher education. The application value of the development of knowledge economy makes knowledge further, the economic globalization and rapid development of science and technology, knowledge, quick update has contributed to the society in the field of practical production knowledge of science and technology innovation, human capital and other elements. Supply knowledge elements in higher education development to adapt to social development and meet the production factors for knowledge in the field of practical need of diversification and individuation, strengthen the refinement of the specialization. Derived can meet the different needs of higher education institutions, contributed to the higher education in the field of "ecological diversity.

The diversification of social development demand, personalized mainly manifested in the following aspects:

(1) The quality requirements. Sustainable capacity requirements. Knowledge update quickly requirements on talent cultivation of higher education not only pay attention to the discipline system to master professional knowledge and professional skill skillfully use [7]. His pay more attention to the sustainable ability, in order to adapt to changing jobs require continuous development, improve human capital.

(2) The number of requirements. Popularization of higher education, popularize, diversification, diversification requirements. Knowledge economy developed countries, the higher education from the elite education gradually stepped into the stage of popularization of higher education, popularize. Quantity demand is not only reflected on the quantity of talent, talent structure types, but also in the school subjects and forms of running a school and diversification of products and services, so as to meet the needs of field production practice.

(3) The space requirements. Different, different social groups in the field of practical demand for higher education. With deep knowledge economy to the society and a wider scope of development, knowledge economy has early by the high-tech sector to expand to a wider range of services [8]. The demand for higher education also by the expansion of the workplace to different social groups. The construction and development of a learning society widely Shared.

(4) Time requirements. After the demand of higher education. Knowledge update quickly made after the 
demand of the higher education is more and more urgent. Lifelong education, adult on-the-job continuous learning attaches great importance to by the society. Higher education by the pre-service education development to after the lifelong education.

With the development of knowledge economy, the increasing maturity of knowledge factor market to promote the realization of knowledge value, industrialization, marketization operation to promote the effective configuration of knowledge elements, stimulating the enthusiasm of the knowledge innovation. Especially the rapid development of information technology, globalization, the division of labor and cooperation, further accelerate the transformation of knowledge update, achievements, improve the efficiency of the development and application of knowledge elements, promote the development and change in the field of higher education. "Ecological environment" to some extent determines the developed degree of higher education. Good "ecological environment" able to attract talents from all over the world. Brings together the world's elite higher education is inevitable in the era of knowledge economy release enormous energy, create enormous wealth of knowledge, and promote the development of industry and national economy.

\section{THE PRODUCTION PRACTICE TO PROMOTE THE}

\section{CHANGE OF THE SCALE OF HIGHER EDUCATION QUALITY}

In based on the knowledge of the knowledge economy society, the laborers engaged in social production practice mostly have certain professional knowledge and skills of knowledge workers [9]. Social production practices to promote higher education universal, lifelong. Professional and technical personnel as the backbone of the social development. Primary professionals have universal access. Senior professional personnel proportion is relatively high. Therefore, developed higher education become the important foundation of the knowledge economy society. Only realize the popularization of higher education, can meet the demand for professional talents of knowledge economy. However, senior professional talents cultivation is still need to elite, especially the practice of applied domain experts through simple teaching activities is difficult to achieve scale cultivation. Its need long-term professional research and accumulated abundant practical. And concrete production practice for the growth of the applied senior specialized talents has provided a broad space, especially in scientific and technological innovation as the core of innovative enterprise will become the main body of cultivating senior professionals.

After continuing education is an important part of the development and supply of knowledge elements, it is the national innovation system, an important part of lifelong education system. Promoting the lifelong education, social production practice after continuing education for prosperity and development. After closely connected with the production practice of continuing education in the era of knowledge economy get unprecedented development. It with specific corporate universities have sprung up combining the production practice of rapid development. It to create a learning society plays an irreplaceable important role, at the same time promote employees' career development plays an important role. After continuing education in the knowledge rapid updating of the knowledge economy era. Their close contact with the production practice of advantage to adapt to the development of knowledge economy, to meet the needs of production practice, also made its own big development boom. After continuing education service includes market, the market profit oriented after continuing education training services.

In addition, higher education object to pre-service school-age youth as the main body is expanding to middleaged and old different ages, different social classes, different social groups and industry organizations. It is more open, inclusive, professional education serve the society, service production functions have been further improved.

\section{THE PRODUCTION PRACTICE PROMOTED THE CHANGE OF HIGHER EDUCATION PERSONNEL TRAINING}

Pay attention to the comprehensive ability of cultivating talented person, the sustainable development ability. Professional knowledge update speed of the knowledge economy era. The need to connect closely with the production practice of talent cultivation. Needs to be updated timely insight into industry professional knowledge development, in order to satisfy the demands of the production practice of talent [10]. Professional education in strengthening academic basic specialized knowledge, learning to master the basic principles of at the same time, strengthen the cultivation of professional practice ability. By establishing the perfect professional education institutional mechanisms and regulations related to close contact with the production practice of the education, integrate their knowledge resources, strengthen the cultivation of professional practice ability, avoid the disconnection between theory and practice, to promote the understanding of professional knowledge and skills to master and migration, promote the professional knowledge and skills to update, so as to adapt to the development of knowledge economy.

Highlight the value of the knowledge economy society, people, people no longer subservient to the machine, but the main body of innovation and learning. Whether national or enterprise organization's learning ability, innovation ability, should be based on people, internalization and externalization of knowledge become the core element factors of human capital. Professional education in talents training target and more emphasis on people-oriented. Pay attention to general ability, innovation ability, the cultivation of learning ability and comprehensive ability. Cultivate plasticity, mastering many skills while specializing in inter-disciplinary talent. Pay more attention to an and mind quality of personality education. Pay more attention to the balance of the comprehensive ability and comprehensive development of education. Develop sustainable ability, sustainable development ability, to adapt to the professional post update knowledge and skills.

\section{THE PRODUCTION PRACTICE TO PROMOTE THE CHANGES OF CONTENTS AND FORMS OF THE HIGHER EDUCATION}

The quality of higher education continuously improve, enrich the content of form. With the increasingly rich 
education resources, intelligent technology popularization and application of information technology. The deepening of the professional teaching and research, as well as the ability to provide personalized, customized development of the education training market. Constantly improve the quality of professional education and professional level. Increasingly rich learning program to satisfy various needs, learning style, education mode to obtain unprecedented breakthrough. Learners cannot restricted by space-time freedom for intelligent, personalized, customized education services, can achieve high simulation study of virtual scene, easy access to high-quality education resources can be anywhere at any time, realize autonomous in learning, to realize online real-time interaction learning.

\section{PRODUCTION PRACTICE TO PROMOTE THE} PERFECTION OF THE FUNCTION OF HIGHER EDUCATION

Social production practice to promote the perfection of the social function of modern higher education, and promote the environment for the development of higher education has been continuously improved. Based on the knowledge of the knowledge economy society, professional education, professional research for various fields of social production practice began to supply professional talents and to provide scientific and technological innovation achievement. Therefore, institutions of higher education become the development of knowledge supply factors important to the production department. And the quality of professional education structure level scale layout directly affect national industry development and economic development. Higher education has an important strategic position in the economic and social development, become the key to the development of national strategy. In addition, the preservice professional education and in-service continuing education constitute the national lifelong education system, science and technology innovation system, and play an important role in the process of creating a learning society.

In countries play an efficient integration advantage, it make up for the lack of market at the same time, the status of the market mechanism function advantage is still hard to replace. Knowledge economic society to establish perfect the factor market and the protection of intellectual property rights and the transfer of the system of laws and regulations, establish and improve the promotion of institutional environment, the mechanism of knowledge transformation for universities, research institutes, education training institutions, and many other professional education professional research subject of intellectual property rights to sell and transfer provides the trading platforms and system guarantee. Development of entrepreneurial university, and to promote knowledge capitalization, accelerate the transformation of knowledge to real productivity. The market mechanism to efficiently allocate knowledge resources rationally, will offer a inexhaustible driving force for knowledge innovation. Market mechanism can effectively promote different joint research and development, cooperative research, professional research subject to further stimulate its knowledge innovation vigor and enthusiasm. Market mechanism to promote professional education training institutions of different types of different attributes for effective collaboration, forming education alliance, realize resources sharing complementary advantages. The vigorous development of professional education, professional research effectively promote the knowledge of the efficient implementation of application value, promote the efficient transformation of knowledge to practical productivity, so as to adapt to the development of knowledge economy, to meet the need of social production practice.

\section{CONCLUSIONS}

In the knowledge economy society, social production practice of the knowledge factors great impact on the development of modern higher education. The production practice has important influence, Whether it is a type of higher education level, quality, professional setting, discipline development, scale and professional knowledge, professional personnel training, and even the social function of higher education, the development environment. In production practice in the society of knowledge economy, basic reason that higher education is an important influence is lies in the knowledge element function in social production practices. Social production practices have positive role to the development of higher education.

\section{REFERENCES}

[1] Wu Feng. Based on the theory of enterprise model of human fields Modern distance education research [J]. 2012, (3) : 75 - a - 79.

[2] Zhang Jing. Enterprise university research [M]. Beijing: economic science press, 2011 (8) : 27.

[3] Song Xiling. Based on the perspective of adult education enterprise development research at the university of $[\mathrm{J}]$. Journal of hubei university adult education college, 2012, (10).

[4] Wu Feng. Enterprises to study research, based on the perspective of learning innovation [M]. Beijing: Beijing humanism publishing house. 2013.

[5] Gao Qin and Long Yong, chang-lin ma, wen-liang guan Mechanical and electrical integration of liquid system modeling and simulation technology $[\mathrm{M}]$. Beijing: electronic industry press. 2012.

[6] Wu Feng, the silver. And the trend of development of the enterprise to study research field. The higher engineering education research [J]. 2012, (4) : November 16.

[7] Allen, Mark. Corporate Universities. Globalization and Greater Sophistication[J]. Journal of International Management Studies,2010, 5(1): 48-53.

[8] LuiAbel. Exploring the corporate university phenomenon: Development and implementation of a comprehensive survey [J].human resource development quarterly. 2012. 23 (1) :26-31.

[9] Xue Song li. Enterprises from four different point of view to study [J]. Engineering machinery today, 2009, (12) : 124-126.

[10] Allen, Mark. Corporate Universities: Globalization and Greater Sophistication[J]. Journal of International Management Studies, 2010,5(10):48-53. 